Monopolvinsten och dess beskattning, jämte något om gross- och detaljhandelspris Author(s): Knut Wicksell

Source: Ekonomisk Tidskrift, Årg. 14, häft 11 (1912), pp. 432-433

Published by: Wiley on behalf of The Scandinavian Journal of Economics

Stable URL: http://www.jstor.org/stable/3437467

Accessed: 27-06-2016 09:59 UTC

Your use of the JSTOR archive indicates your acceptance of the Terms \& Conditions of Use, available at

http://about.jstor.org/terms

JSTOR is a not-for-profit service that helps scholars, researchers, and students discover, use, and build upon a wide range of content in a trusted digital archive. We use information technology and tools to increase productivity and facilitate new forms of scholarship. For more information about JSTOR, please contact support@jstor.org.

Wiley, The Scandinavian Journal of Economics are collaborating with JSTOR to digitize, preserve and extend access to Ekonomisk Tidskrift 


\section{Monopolvinsten och dess beskattning, jämte något om gross- och detaljhandelspris.}

Efter genomläsande af doc. Brocks uppsats öfver monopolprisbildningen i septemberhäftet af Ekon. Tidskr. fäste jag hans uppmärksamhet på, att hans däri framställda anmärkningar mot min behandling af ämnet saknade grund och bad honom att för enkelhetens skull själf införa nödig rättelse. Detta har han också gjort, dock utan att omnämna anledningen.

Samtidigt framkommer han emellertid med nya anmärkningar, som torde vara lika litet berättigade: jag skall ha förbisett, att monopolisten ocksă måste beräkna ränta på sitt kapital, samt på själfva skatten i den mån den af honom förskotteras. Har jag verkligen förbisett detta? Enligt vanligt språkbruk plägar man väl inräkna en affärsmans ränteutlägg bland hans omkostnader. ${ }^{1}$ I de af Brock valda exemplen skulle jag för min del icke sagt, att monopolistens omkostnader utgjort $4 \mathrm{kr}$. (resp. I6 kr.) pr styck, motsvarande blotta arbetskostnaderna, utan, inberäknadt räntan, 4 kr. 20 öre (resp. I6 kr. 80 öre); och då vid den antagna lagen för afsättningen optimumpriset för monopolisten alltid stiger med halfva beloppet af omkostnaderna, måste det ju i detta fall ökas med Io (resp. 40) öre. Därmed förfalla, så vidt jag kan se, Brocks samtliga anmärkningar rörande denna sak.

Hvad åter skatten beträffar, har jag visserligen utgått från, att den af monopolisten erlades vid varans försäljning, alltså icke i förskott. Men detta torde också öfverensstämma med modern skattepraxis. Våra bryggare t. ex. ha ju enligt maltskattelagen, om de ställa borgen, rätt att dröja med skattens inbetalande intill fem månader och i genomsnitt c:a $3 \frac{1}{2}$ månad efter maltets uppvägande; under den tiden bör en brygd hinna att både lagras och konsumeras. Att de, såsom Brock antager, skulle ligga i förskott med maltskatten under ett helt år, torde näppeligen någonsin förekomma, om icke vid konkurs hos källarmästare l. dyl.

Men i hvarje fall blir ju den häraf nödvändiggjorda korrektionen af alldeles samma slag som den förut omnämnda, och torde för hvarje tän-

1 Att våra inkomstskattelagar icke göra detta, beror ju på, att någon särskild kapitalränteskatt $\mathrm{i}$ detta fall icke förekommer - utom i förmögenhetsbeskattningens form. 
kande läsare gifva sig själf. Var det då skäl att öda tid och tidskriftsutrymme med dylika enkla kalkyler?

Efter jag gripit till pennan, kan jag på samma gång få säga, att doc. Brocks utredning angående detaljprisens förhållande till grosshandelsprisen (i bil. B. till den första uppsatsen) icke tillfredsställer mig. Han säger sig där aldrig ha menat annat, än att detaljprisen gå ned under baissen lika mycket som de gått upp under haussen, blott att det sker på ett mera dröjande sätt - alltså förmodligen först mot slutet af hvarje baisse, men då så mycket mera energiskt. En dylik gestaltning af prisrörelsen öfverensstämmer dock icke med de statistiska kurvor, på hvilka han ville stöda sitt resonemang, icke heller med det yttrande af Lexis, som han nu åberopar.

Om den vore faktiskt riktig, så skulle för öfrigt konsumenternas intresse häraf icke nämnvärdt beröras. Detaljprisen måste ju i hvarje fall stå högre än grosshandelsprisen, om då spänningen mellan dem enligt förutsättningen skulle vara något högre under baissen än under haussen, kan ju detta vara konsumenterna ganska egalt, blott den icke i genomsnitt är allt för hög - naturligtvis äro de dock ännu bättre betjänta med fullt stabila pris. Helt annat om, såsom Lexis uttryckligen påstår och som jag antog att äfven Brock menat, detaljhandlarna under baissen, »blott delvis eller alls icke» skulle sänka sina pris, men däremot under haussen alltjämt höja dem, pari passu med grosshandelsprisen. Då skulle spänningen mellan dessa båda prisgrupper oafbrutet ökas med hvarje kreditcykel, och konsumenterna blefvo naturligtvis lidande i proportion - men detta är tydligen ett antagande, som intet mătt af auktoritet kan göra till annat än en orimlighet, $\mathrm{i}$ fall det nämligen fattas såsom allmän regel.

Däremot har jag aldrig nekat, att en sådan företeelse tidvis kan äga rum och särskildt $\mathrm{i}$ vår tid torde ha inträffat $\mathrm{i}$ samband med den starka och nationalekonomiskt sedt irrationella ökningen af antalet detaljhandlare, hvilken, såsom jag sökt visa, just måste ha denna effekt.

Knut Wicksell.

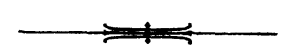

